\title{
Ecological traits of dragonfly (Odonata) assemblages along an oligotrophic Dinaric karst hydrosystem
}

\author{
Marina Vilenica* \\ University of Zagreb, Faculty of Teacher Education, Trg Matice hrvatske 12, 44250 Petrinja, Croatia
}

Received: 30 March 2017; Accepted: 27 August 2017

\begin{abstract}
Ecological traits of dragonfly larvae in tufa-depositing habitats of the Dinaric karst were studied monthly over a one-year period (2007-2008). The study encompassed various lotic karst habitats (springs, mountainous rivers, streams, tufa barriers) and microhabitats (angiosperms, mosses, cobbles, sand, silt with leaf litter). The aims of the study were to identify dragonfly composition, abundance and spatial distribution, their habitat and microhabitat preferences, and to determine the most important environmental factors explaining dragonfly assemblages in the studied hydrosystem. The dragonfly fauna was composed of eight species, Onychogomphus forcipatus (Linnaeus, 1758) was the most widespread and the most numerous. Water temperature, ammonium and oxygen concentrations had the highest influence on dragonfly assemblages. The most favorable habitat type were tufa barriers, less favorable were lower lotic habitats, while dragonflies were almost completely absent from upper lotic habitats and their springs. Dragonfly larvae preferred microhabitats with inorganic substrates (i.e. cobbles and sand) and slower water velocity, while they mostly avoided mosses associated with the strongest current. This study provides an important contribution to the knowledge of dragonfly ecology in lotic habitats of the Dinaric karst.
\end{abstract}

Keywords: Odonata / case study / tufa barriers / environmental factors / microhabitats

\section{Introduction}

Odonata is an ancient hemimetabolous insect order dating back into the Permian period with roots into the Carboniferous (Askew, 2004; Grimaldi and Engel, 2005). With almost 6300 described extant species (Schorr and Paulson, 2017), of which about 143 inhabit European freshwater habitats, it is a relatively small insect order (Kalkman et al., 2008; Boudot and Kalkman, 2015). With aquatic larvae that inhabit both running and standing waters, and aerial adults, they represent an important link between freshwater and terrestrial habitats (Askew, 2004; Corbet and Brooks, 2008). Dragonfly species often have specific demands for the morphology, structure and chemistry of their habitats. Bottom substrate, submerged aquatic vegetation and water clarity are among the important habitat characteristics for larvae, while the adults select their habitat primarily basing on factors such as vegetation structure and shading (Buchwald, 1992; Steytler and Samways, 1995; Askew, 2004; Corbet and Brooks, 2008). Their conspicuousness and sensitivity to small-scale changes in environmental conditions make them good bio-indicators and one of the key organisms for a rapid quality assessment of

\footnotetext{
*Corresponding author: marina.vilenica@gmail.com
}

freshwater habitats (Corbet, 1993; Moore, 1997; Mortimer et al., 1998). Both larvae and adults are generalist predators that mainly feed on various small invertebrates. They are also an important food source for diverse freshwater and terrestrial predators (Askew, 2004).

Karst is a complex landscape constituted of morphological, hydrological and hydrogeological terrain features underlain by soluble carbonaceous rocks. Karst landscape is also characterized by an extremely complicated hydrological network. An important characteristic of karst freshwater habitats is the formation of tufa from secondary biogenic calcium-carbonate precipitation (Bonacci and Jelin, 1988; Bonacci et al., 2013). The studied lotic habitats of Plitvice Lakes National Park (NP) are located in the largest continuous karst landscape in Europe, the Dinaric Mountains, which extend over approximately $60000 \mathrm{~km}^{2}$ (Mihevc et al., 2010). In the studied hydrosystem, the biological component is a key factor in development of another karst phenomenon - tufa dams. The tufa dams cause the differentiation of a river profile into a cascade lake system (natural barrage lakes) (Srdoč, 1985).

Although the first studies on Croatian dragonflies date back to the second half of the 19th century (Carrara, 1846), our knowledge began to increase during the early 21 st century (e.g. Bogdanović et al., 2008; Vilenica et al., 2011, 2016a; Vilenica and Dijkstra, 2014; Štih et al., 2015). In 2008, Belančić et al. presented the most comprehensive data in the 


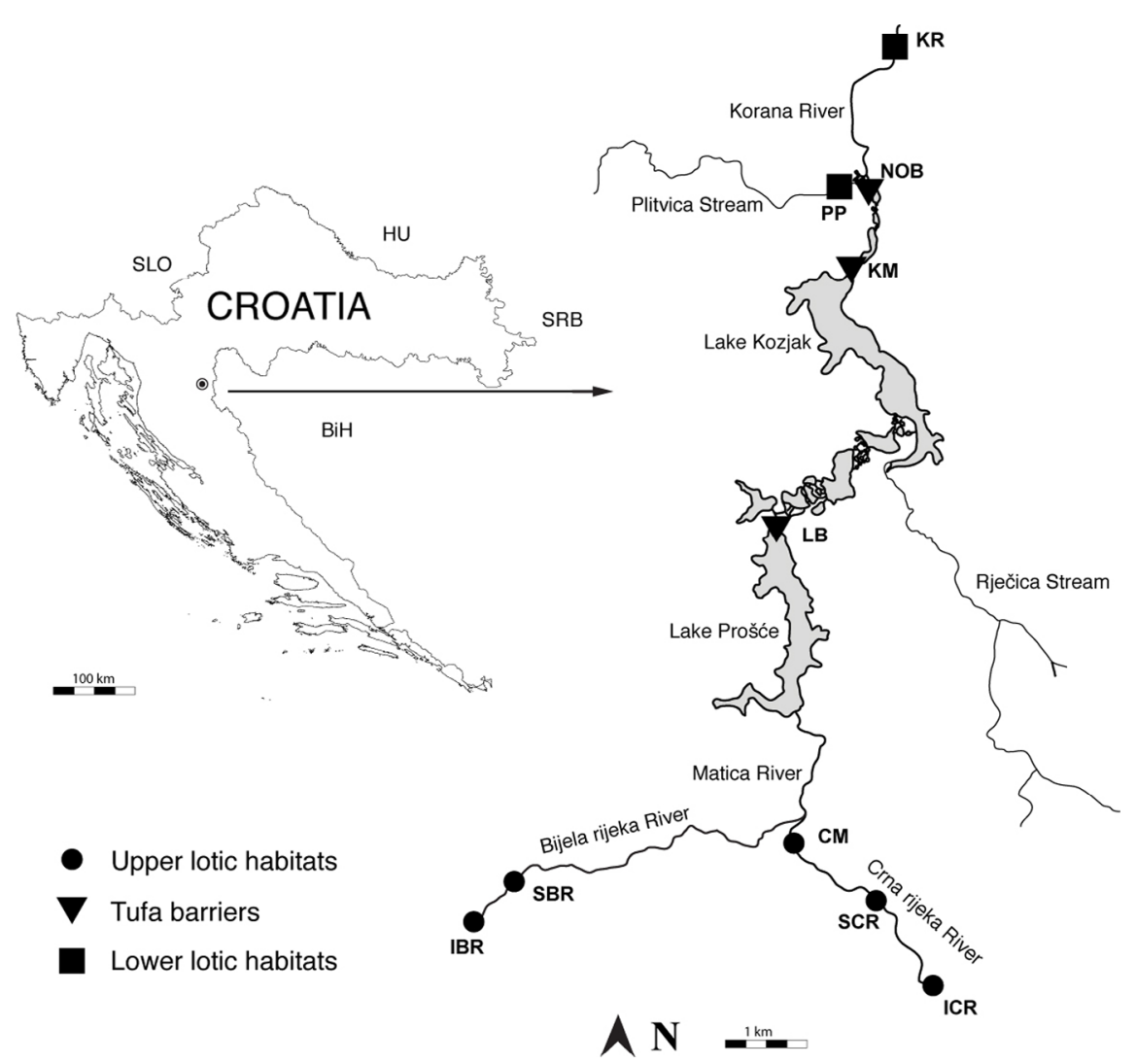

Fig. 1. Location of Plitvice Lakes NP in Croatia and position of ten study sites in Plitvice Lakes NP. Legend: IBR = Bijela rijeka River spring, $\mathrm{SBR}=$ Bijela rijeka River upper reaches, $\mathrm{ICR}=$ Crna rijeka River spring, $\mathrm{SCR}=$ Crna rijeka River middle reaches, $\mathrm{CM}=\mathrm{Crna}$ rijeka $\mathrm{River}$ lower reaches, $\mathrm{KR}=$ Korana River, $\mathrm{PP}=$ Plitvica Stream, $\mathrm{KM}=$ Tufa barrier Kozjak-Milanovac, $\mathrm{LB}=$ Tufa barrier Labudovac, $\mathrm{NOB}=\mathrm{Tufa}$ barrier Novakovića Brod. Figure modified from Vilenica et al. (2014).

Red Book of Dragonflies. Yet, there are still some gaps in our knowledge of dragonflies in the Dinaric karst area (i.e. their distribution and ecology), which limits protection of species and their habitats as well as management of important areas. Faunistic and ecological studies concerning various aquatic insects of the Dinaric karst have increased in recent years, such as Plecoptera (Popijač and Sivec, 2009), Trichoptera (e. g. Šemnički et al., 2012; Kučinić et al., 2015), Diptera (Empidide (e.g. Ivković et al., 2012) and Simuliidae (Ivković et al., 2013)), Coleoptera (Elmidae (Mičetić Stanković et al., 2015)) and Ephemeroptera (e.g. Vilenica et al., 2016b, 2017). Nevertheless, a number of comprehensive studies on dragonfly ecological traits in karst freshwater habitats remained rather low (e.g. Pešić et al., 2017). Numerous limnological studies conducted in tufa-depositing habitats of Plitvice Lakes NP reported dragonflies, but only sporadically as a part of macroinvertebrate benthic communities (e.g. Matoničkin, 1959; Matoničkin et al., 1971; Habdija et al., 2004; Sertić Perić et al., 2015), without focusing on their ecological preferences

Therefore, the main goals of this study were to determine:

- composition, abundance and spatial distribution of dragonflies;

- dragonfly habitat and microhabitat preferences;

- environmental factors that have the highest influence on dragonflies in the selected tufa-depositing lotic habitats of Plitvice Lakes NP.

\section{Material and methods}

\subsection{Study area}

Plitvice Lakes NP is located in the Dinaric karst region in Croatia $\left(44^{\circ} 51^{\prime} \mathrm{N}, 15^{\circ} 34^{\prime} \mathrm{E}\right)$. In 1979 , it was recognized as a world natural heritage site and protected as such by UNESCO (IUCN, 1979). The Plitvice barrage-lake system consists of 16 meso-oligotrophic and oligotrophic, dimictic and fluvial lakes (Miliša et al., 2006; Špoljar et al., 2007; Gligora Udovič et al., 2017) separated by tufa barriers (Fig. 1). Small mountainous rivers at the beginning of the barrage-lake system, Bijela rijeka and Crna rijeka, join together to form the Matica River, the main surface-water supply for the lakes (Stilinović and Božičević, 1998). The area of the Park is influenced by temperate and boreal climates (Köppen climate classification; Šegota and Filipčić, 2003). Mean annual air temperature during the study period was $11.4^{\circ} \mathrm{C}$ (mean spring temperature was $16.6^{\circ} \mathrm{C}$ and mean summer temperature was $18.3^{\circ} \mathrm{C}$ ). Annual rainfall was $1664.1 \mathrm{~mm}$ (www.meteo.hr).

\subsection{Dragonfly sampling and identification}

Sampling was conducted monthly between February 2007 and February 2008 at ten study sites located in various karst lotic freshwater habitats. Due to their position within the 


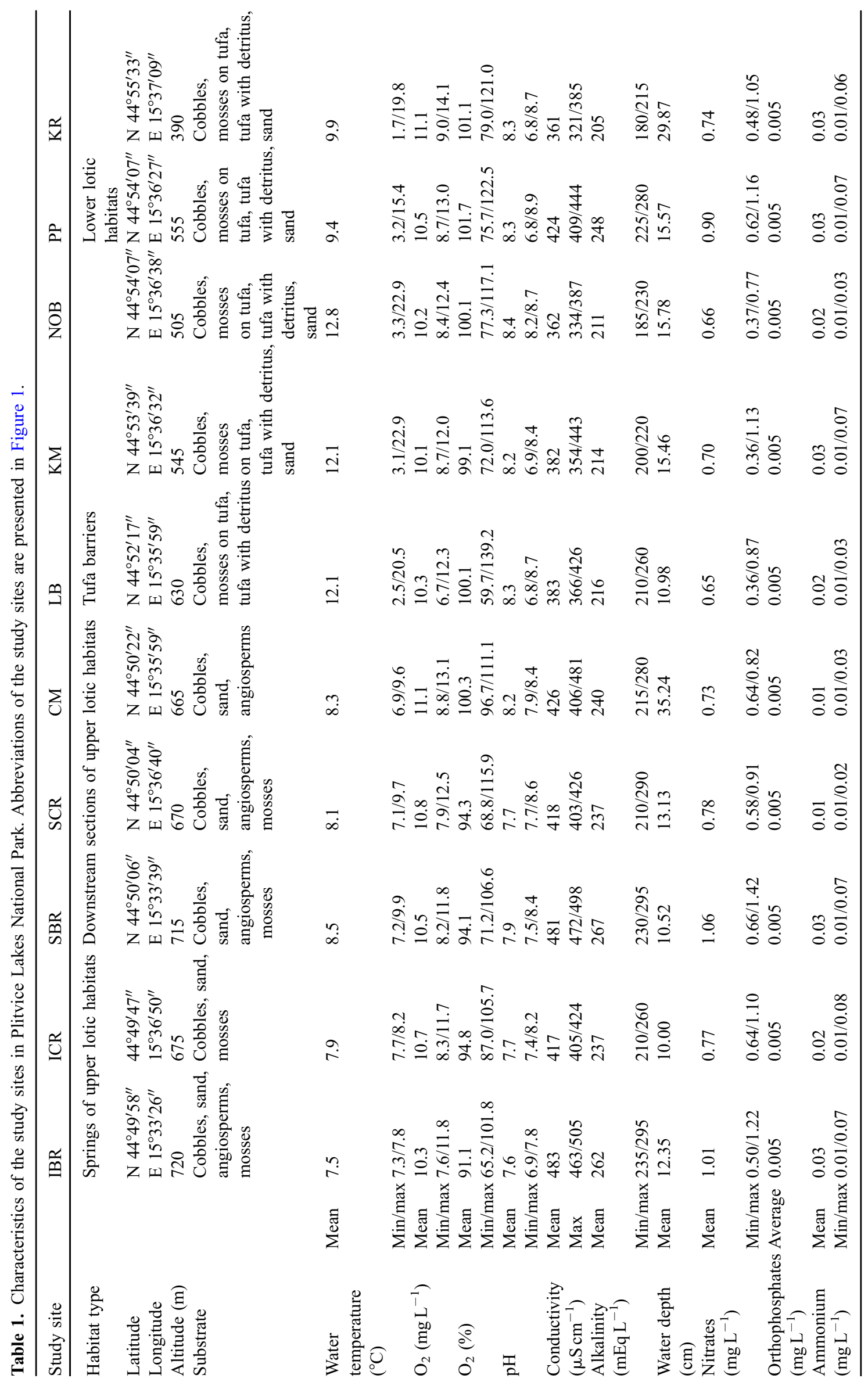


barrage-lake system, their altitude and habitat type, investigated habitats were classified into the following categories (Fig. 1, Tab. 1):

- upper lotic habitats at the beginning of the barrage-lake system represented by;

- rheocrene springs of small mountainous rivers: spring of the Bijela rijeka River (elevation $720 \mathrm{~m}$ ) (IBR) and spring of the Crna rijeka River (675 m) (ICR),

- downstream sections of small mountainous rivers: upper reaches of the Bijela rijeka River (716 m) (SBR), middle reaches of the Crna rijeka River $(670 \mathrm{~m})$ (SCR) and lower reaches of the Crna rijeka River $(665 \mathrm{~m})$ $(\mathrm{CM})$,

- tufa barriers, situated between upper and lower lotic habitats: Tufa barrier Labudovac $(630 \mathrm{~m})$ (LB), Tufa barrier Kozjak-Milanovac (545 m) (KM) and Tufa barrier Novakovića Brod (505 m) (NOB);

- tufa-depositing lower lotic habitats at the end of the cascade system represented by a canyon type mountainous stream, Plitvica Stream $(555 \mathrm{~m})(\mathrm{PP})$ and a mid-altitude large river, Korana River (390 m) (KR).

At each site, triplicate samples were taken every month in all major microhabitat types with a share of at least 5\% coverage (angiosperms, mosses, cobbles, sand and silt with leaf litter, Tabs. 1 and 2). Substrate categories were defined according to Wentworth (1922).

Dragonfly larvae were sampled together with other macroinvertebrates using Surber samplers (mesh size: $0.5 \mathrm{~mm}$; surface area: $14 \times 14 \mathrm{~cm}$ on mosses and $25 \times 25 \mathrm{~cm}$ on all other microhabitats). The exception was a site on the lower reaches of Crna rijeka River (CM), where due to the greater water depth, macroinvertebrates were sampled using a D-frame hand net (mesh size: $0.5 \mathrm{~mm}$; surface area: $25 \times 25 \mathrm{~cm}$ ). Samples were conserved in $80 \%$ ethanol. Abundance was calculated as number of individuals per $\mathrm{m}^{2}$ to allow comparison of different sized samples. Dragonflies were identified using Gerken and Sternberg (1999) combined with Askew (2004) and Brochard et al. (2012). All voucher specimens are deposited at the Department of Biology, Faculty of Science, Zagreb, Croatia.

\subsection{Environmental factors}

Physico-chemical water properties were measured monthly at each study site (Tab. 1): oxygen concentration, oxygen saturation, water temperature (using the oximeter WTW Oxi 330/SET), pH (using the pH-meter WTW ph 330), conductivity (with the conductivity meter WTW LF 330), alkalinity (by titration with $0.1 \mathrm{M} \mathrm{HCl}$ ), water velocity (with P-670-M velocimeter), water depth (with handheld meter) and nutrients (orthophosphates by HRN ISO 6878:2001 method, ammonium by HRN ISO 70-3:1998 method and nitrates by HRN ISO 7890-3:2001 method). Water velocity (Tab. 2) and water depth were measured at each sampled microhabitat at each sampling event. Altitude and distance from the springs were determined for each study site.

\subsection{Data analysis}

The Shapiro-Wilk normality test was performed for all data. According to the normality of data, suitable tests were chosen. All species data were log transformed prior to analyses.

Non-metric multidimensional scaling analysis (NMDS) was applied to show similarities in the composition of dragonfly assemblages among study sites using the BrayCurtis similarity index. Study sites without dragonfly records were excluded from the analysis. Kruskal-Wallis $H$ test, followed by Multiple comparisons post hoc test were used to determine the preference of dragonfly assemblages (abundance, species richness) and each recorded species for a specific habitat and microhabitat type. Relationship of dragonfly assemblages (abundance, species richness) and each of the recorded species with physico-chemical water properties was analysed using the Spearman's rank correlation coefficient $(R)$. Canonical correspondence analysis (CCA) with Monte Carlo permutation test of significance (with 499 permutations) was used for identification and measurement of dragonflies and environmental conditions. This analysis was performed using data for eight species, 31 sampling points and eight environmental variables (water velocity and depth, water temperature, conductivity, oxygen concentration, nitrates, ammonium and $\mathrm{pH}$ ). Alkalinity was not used in the analysis due to its collinearity with conductivity. Prior to CCA analysis, full draftman's plot excluded orthophosphates.

Analyses were performed in Statistica, version 10.0 (Statsoft Inc., Tulsa, PC-ord ver. 5.0), Primer 6 software package (Clarke and Gorley, 2006) and CANOCO for Windows (ver. 4.02) (Ter Braak and Smilauer, 1998).

\section{Results}

\subsection{Environmental factors}

Physico-chemical water properties of each study site are shown in Table 1. The significant differences in environmental factors between the habitat types are presented in Vilenica et al. (2017). Overall, the highest mean water temperature was recorded at tufa barriers, and the lowest in springs. Moreover, tufa barriers had lower mean oxygen concentration compared to other habitat types. Tufa barriers and lower lotic habitats had higher mean $\mathrm{pH}$ value and slightly lower mean alkalinity and conductivity compared to upper lotic habitats. Mean nitrate concentration was higher in springs compared to other habitat types, while springs and lower lotic habitats had higher mean ammonium concentration. Phosphate concentration was the same at all study sites during the whole study period (Tab. 1). Among the studied microhabitats, mean water velocity was generally the highest on the mosses, and the lowest on the silt with leaf litter (Tab. 2).

\subsection{Dragonfly assemblages}

In lotic habitats of the studied hydrosystem, dragonfly larvae were mainly recorded in the samples collected in the period between March and September, and a total of eight species were documented (Tab. 3). The most widespread and the most abundant species was Onychogomphus forcipatus (Linnaeus, 1758), while Coenagrion puella (Linnaeus, 1758) and Gomphus vulgatissimus (Linnaeus, 1758) were the rarest recorded species. 
Table 2. Average annual water velocities with minimum and maximum values at different microhabitats in Plitvice Lakes NP located in: (a) upper lotic habitats (springs and downstream sections) and (b) tufa barriers and lower lotic habitats. Abbreviations of the study sites are presented in Figure 1. Legend: S1 = cobbles, S2= angiosperms, S3 = mosses, S4= sand, S5 = silt with leaf litter.

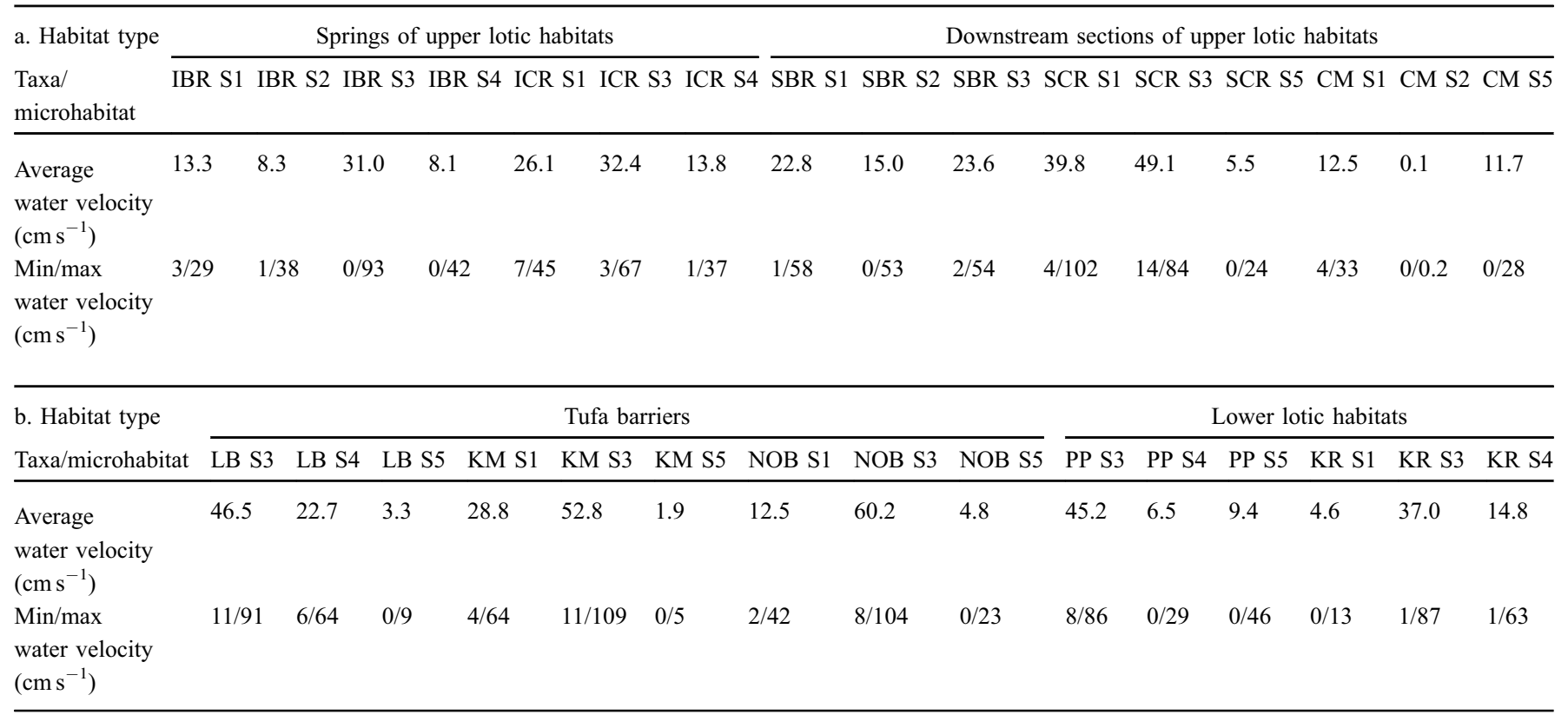

According to the NMDS analysis (Fig. 2), lower lotic habitats mutually shared $90 \%$ similarity and $70 \%$ similarity with Tufa barrier Novakovića Brod (NOB). All three sites showed $50 \%$ similarity with other two tufa barriers: Tufa barrier Kozjak-Milanovac (KM) and Tufa barrier Labudovac (LB). Study site middle reaches of the Crna rijeka River (SCR) separated independently.

According to the Kruskal-Wallis $H$ test, differences in dragonfly assemblages (species richness $(H \quad$ (3, $N=366)=83.76, \quad p<0.001)$ and abundance $(H \quad(3$, $N=366)=82.65, p<0.001)$ ) were significant between the habitat types. Multiple comparisons post hoc test showed that species richness was different between tufa barriers and the following habitats: springs $(p<0.001)$, downstream sections of upper lotic habitats $(p<0.001)$ and lower lotic habitats $(p<0.05)$. Abundance differed between tufa barriers and springs $(p<0.001)$ and between tufa barriers and downstream sections of upper lotic habitats $(p<0.001)$. Tufa barrier Kozjak-Milanovac had the highest species richness, i.e. six, while the highest abundance was recorded at Tufa barrier Novakovića-Brod $\left(222.8 \mathrm{~m}^{-2}\right)$. Dragonfly larvae were completely absent from Bijela rijeka River, and very rare in Crna rijeka River, where in the middle reaches of the river, only one species (Cordulegaster bidentata (Selys, 1843)) was recorded in very low abundances (Tab. 3).

Kruskal-Wallis and multiple comparisons post hoc test showed significant differences in abundance of $O$. forcipatus $(H(3, N=366)=71.71, p<0.001)$ between tufa barriers and springs $(p<0.001)$ and tufa barriers and downstream sections of upper lotic habitats $(p<0.001)$. The species was most abundant in tufa barriers and completely absent from upper lotic habitats (Tab. 3). Additionally, Kruskal-Wallis $H$ test showed there were significant differences in abundances of Orthetrum coerulescens (Fabricius, 1798) (H (3,
$N=366)=29.29, p<0.001)$, Platycnemis pennipes (Pallas, $1771)(H(3, N=366)=14.42, p<0.001)$ and Calopteryx virgo (Linnaeus, 1758) $(H(3, N=366)=14.41, p<0.001)$ between the habitat types, but multiple comparisons post hoc test could not determine between which groups differences existed. Nevertheless, $O$. coerulescens and $C$. virgo were recorded only at tufa barriers. P. pennipes inhabited also lower lotic habitats, but was more abundant in tufa barriers (Tab. 3).

\subsection{Dragonflies and environmental factors}

The eigenvalues for the first two CCA axes (Fig. 3) were 0.47 and 0.30 , and accounted for $49.5 \%$ of the variability in species-environment relations. The Monte Carlo permutation test showed that the species-environment ordination was significant (first axis: $F$-ratio $=3.02, p=0.04$; overall: trace $=$ $1.13, F=2.25, p=0.004)$, indicating that dragonfly assemblages were significantly related to the tested set of environmental variables. Axis 1 was related to ammonium concentrations $(R=-0.60)$ and water temperature $(R=-0.42)$ and Axis 2 to oxygen concentration $(R=0.64)$, indicating that these were the most important parameters in explaining patterns of dragonfly assemblages.

Significant correlations of dragonfly assemblages (species richness $(\mathrm{S})$, abundance $(\mathrm{N})$ ) and five dragonfly species with environmental factors are presented in Tables 4 and 5.

\subsection{Dragonflies and microhabitat selection}

Kruskal-Wallis $H$ test performed on dragonfly assemblages showed significant differences between abundance $(H(3$, $N=208)=13.16, p<0.01)$ and species richness $(H$ (3, $N=208)=12.86, p<0.01)$ at different microhabitats. Multiple 
M. Vilenica: Ann. Limnol. - Int. J. Lim. 53 (2017) 377-389

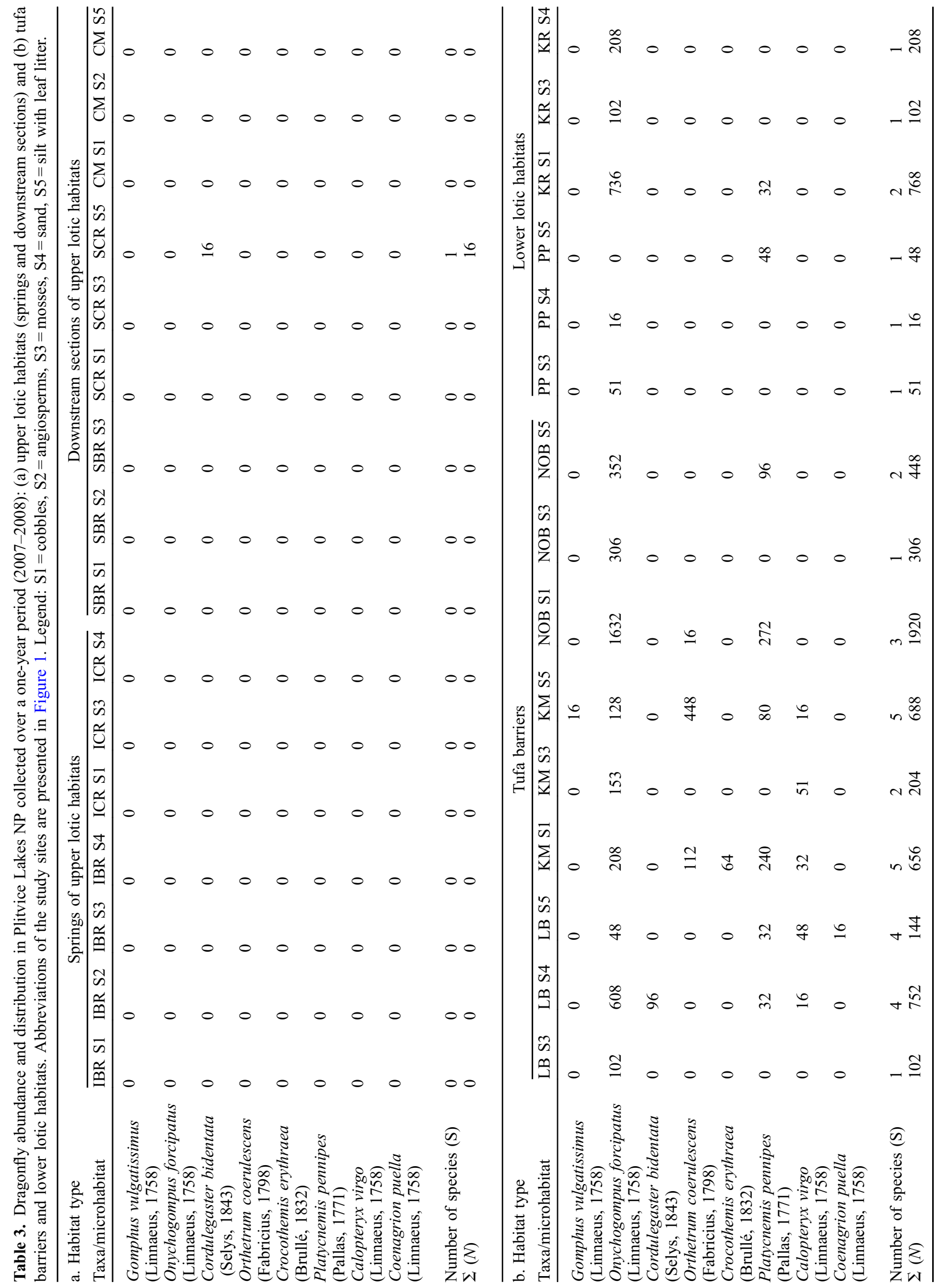




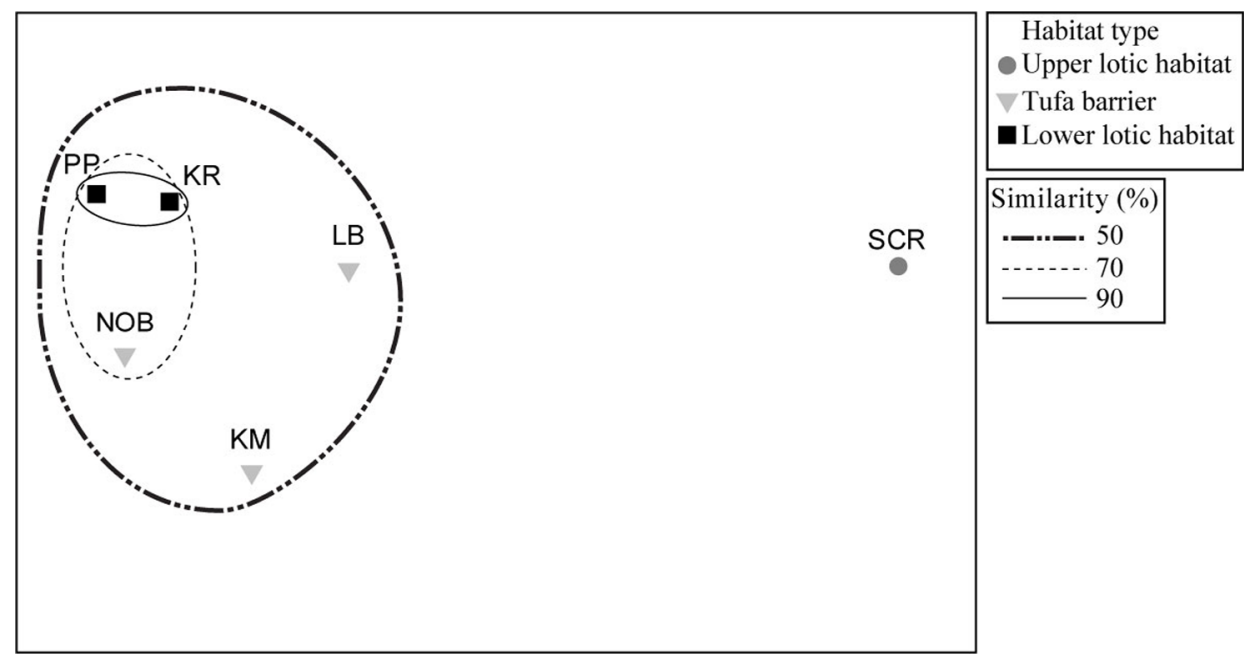

Fig. 2. NMDS analysis of the study sites in different habitat types in Plitvice Lakes NP based on the composition of dragonfly fauna shown pooled per study site. Study sites with dragonfly records: $\mathrm{SCR}=$ Crna rijeka River middle reaches, $\mathrm{PP}=\mathrm{Plitvica} \mathrm{Stream}, \mathrm{LB}=\mathrm{Tufa}$ barrier Labudovac, $\mathrm{NOB}=$ Tufa barrier Novakovića Brod, KM=Tufa barrier Kozjak-Milanovac.

comparisons post hoc test showed that there were significant differences $(p<0.5)$ between cobbles and mosses, with the highest species richness and abundance recorded on cobbles and the lowest on mosses (Tab. 3). Both species richness (S) and abundance $(\mathrm{N})$ were negatively correlated with water velocity at different microhabitats $(N=210 ; R=-0.16$, $R=-0.18 ; p<0.05)$.

Kruskal-Wallis $H$ test performed on the species level showed a significant difference between the abundances of individuals at different microhabitats for $O$. forcipatus $(H(3$, $N=174)=17.79, \quad p<0.001), \quad P$. pennipes $\quad(H \quad(3$, $N=174)=19.18, \quad p<0.001)$ and $C$. bidentata $(H \quad(3$, $N=70)=15.24, p<0.01)$. Multiple comparisons post hoc test showed that there were significant differences in the abundance of $O$. forcipatus between cobbles and mosses $(p<0.01)$, with the highest abundances of the species found at cobbles. For other two species, the latter test could not determine between which groups differences existed. Nevertheless, the presence of five most numerous species on different microhabitats is presented in Figure 4. The highest number of $P$. pennipes individuals were recorded in cobbles, while the highest number of $C$. bidentata individuals were found in sand. Additionally, larvae of $O$. coerulescens mainly chose silt with leaf litter, whereas $C$. virgo inhabited all available microhabitats. $P$. pennipes was negatively correlated with water velocity $(N=174, R=-0.19, p<0.05)$, while correlations of other species and water velocity at different microhabitats were not significant $(p>0.05)$.

\section{Discussion}

Predatory dragonfly larvae represent an important link in food webs and population structure maintenance in tufadepositing lotic habitats of Plitvice Lakes NP (Knight et al., 2005). However, contrary to some other predatory insects, such as stoneflies (Popijač and Sivec, 2009), or aquatic dance flies (Ivković et al., 2012), this study revealed relatively low dragonfly species richness, i.e. $12 \%$ of Croatian dragonfly fauna (Belančić et al., 2008; Boudot and Kalkman, 2015). Species richness could also be considered relatively low when compared with dragonfly fauna of other lotic habitats in the Dinaric karst (e.g. De Knijf et al., 2013; Kulijer et al., 2013). The studied hydrosystem is characterized by specific environmental conditions, such as low water temperature and low productivity (Miliša et al., 2006; Špoljar et al., 2007; Gligora Udovič et al., 2017). Additionally, as a groundwater dependent ecosystem, with high level of carbonate rocks dissolution, it is also characterized by high alkalinity and conductivity (Bonacci et al., 2009; Calijuri et al., 2012). These conditions could be a challenging surrounding for inhabiting aquatic organisms. The limiting factor for dragonflies was most probably low water temperature throughout the year, in combination with dragonfly habitat preferences (Askew, 2004; Dijkstra and Lewington, 2006; Corbet and Brooks, 2008). Additionally, relatively low abundance of dragonfly larvae could have also been influenced by introduction of several allochthone fish species, which resulted in the change of fish and other aquatic assemblages (e.g. Antonović and Treer, 2015). However, this is also potentially due to limitations of the sampling method which may under-collect representative larvae as the nets cover only a small area of a habitat/ microhabitat (Horning and Pollard, 1978; Hawking and New, 1999; Martín and Maynou, 2016). Even though the studies focusing on dragonfly adults are the most common, they could sometimes show inaccurate results, as adults have high dispersal abilities and could often be found far from the place of their emergence (e.g. Márquez-Rodríguez (2015) found seven species of adult Odonata at an acid-mine polluted river in Spain with a $\mathrm{pH}$ of 2.36 , a habitat where no Odonata are expected to reproduce). On the other hand, the importance of surveying for exuviae has been emphasized in numerous occasions (e.g. Samways et al., 2009; Raebel et al., 2010), as presence of exuviae showed to be the only proof of life-cycle completion at certain habitat. Thus, in order to obtain the most accurate and complete list of dragonfly species in the studied area, future studies should combine larval, exuvial and adult surveys. 


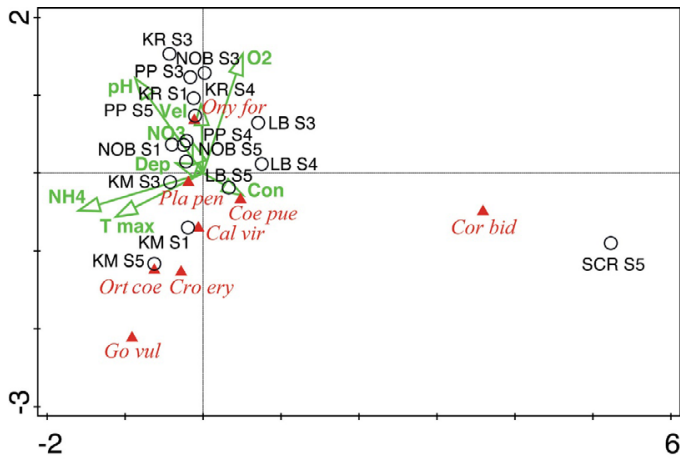

a)

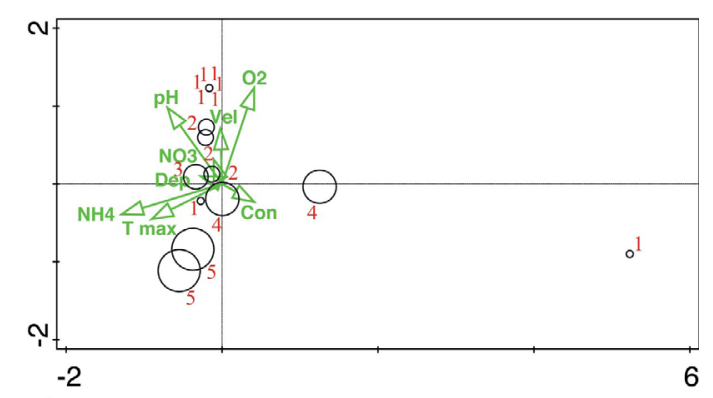

b)

Fig. 3. F1 $\times$ F2 plane of CCA analysis (a) for eight dragonfly species, 31 sampling points and eight selected environmental variables, (b) shown as species richness. Legend: study sites (black circle symbols): $\mathrm{IBR}=$ Bijela rijeka River spring, $\mathrm{SBR}=$ Bijela rijeka River upper reaches, $\mathrm{ICR}=\mathrm{Crna}$ rijeka River spring, $\mathrm{SCR}=\mathrm{Crna}$ rijeka River middle reaches, $\mathrm{CM}=$ Crna rijeka River lower reaches, $\mathrm{KR}=$ Korana River, $\mathrm{PP}=$ Plitvica Stream, KM=Tufa barrier Kozjak-Milanovac, $\mathrm{LB}=$ Tufa barrier Labudovac, NOB $=$ Tufa barrier Novakovića Brod. Microhabitats: $\mathrm{S} 1=$ cobbles, $\mathrm{S} 2=$ angiosperms, $\mathrm{S} 3=$ mosses, $\mathrm{S} 4=$ sand, S5 = silt with leaf litter. Environmental factors (green arrow symbols): $\mathrm{T} \max =$ maximum water temperature $\left({ }^{\circ} \mathrm{C}\right) ; \mathrm{O} 2=\mathrm{O}_{2}$ $\left(\mathrm{mg} \mathrm{L}^{-1}\right) ; \mathrm{pH}=\mathrm{pH}$ value; $\mathrm{Con}=$ conductivity $\left(\mu \mathrm{S} \mathrm{cm}^{-1}\right)$; Vel = water velocity $\left(\mathrm{m} \mathrm{s}^{-1}\right)$; Dep $=$ water depth $(\mathrm{cm}) ; \mathrm{NO} 3=$ nitrates $\left(\mathrm{mg} \mathrm{L}^{-1}\right)$; $\mathrm{NH} 4=$ ammonium $\left(\mathrm{mg} \mathrm{L}^{-1}\right)$. Species (red triangle symbols): Gom $v u l=$ Gomphus vulgatissimus, Ony for = Onychogomphus forcipatus, Cor bid=Cordulegaster bidentata, Ort coe=Orthetrum coerulescens, Cro ery $=$ Crocothemis erythraea, Pla penn=Platycnemis pennipes, Cal vir $=$ Calopteryx virgo, Coe pue $=$ Coenagrion puella .

Habitat selection is a very important dragonfly behavioral trait (Corbet and Brooks, 2008). Many of the European species are predominantly lotic (e.g. as in the genus Cordulegaster) or lentic (e.g. as many species in the genus Aeshna). However, a high number of species can inhabit a wider range of freshwater habitat types that provide them with the required oxygen concentration, variety of microhabitats and food resources (Askew, 2004; Dijkstra and Lewington, 2006). In the current study, tufa barriers - natural lake outlets, showed to be a favorable habitat type. The barriers were inhabited by predominantly lotic (e.g. C. virgo, $G$. vulgatissimus, $C$. bidentata, O. coerulescens), predominantly lentic (e.g. Crocothemis erythraea (Brullé, 1832)) and eurytopic species (e.g. P. pennipes, C. puella) (Janecek et al., 1995; Schmedtje and Colling, 1996; Dijkstra and Lewington, 2006). Moreover, $O$. forcipatus, a species that preferentially inhabits rivers and stony streams, but can occasionally be found in lakes with clear water (Askew, 2004) showed a significant preference for tufa barriers. Limnophilous species, such as $C$. erythraea (Schmedtje and Colling, 1996) present at tufa barriers, probably drifted from the upstream lakes (Sertić Perić et al., 2011). Contrary to some previous studies on karst freshwater habitats (e.g. Pešić et al., 2017), dragonflies were almost completely absent from springs and headwaters of small mountainous rivers, which could be related to relatively low annual water temperature and low abundance of food (e.g. Corbet and Brooks, 2008; Vilenica et al., 2017). C. bidentata, a lotic species that mainly inhabits springs and upper reaches of lower mountainous streams (Janecek et al., 1995; Schmedtje and Colling, 1996; Leipelt, 2005; Boudot et al., 2009), but also occurring in higher altitude habitats with colder water (e.g. Dittmar, 1955; Manenti et al., 2013), was the only one that could cope with such low water temperature. Dragonfly habitat preferences were also reflected in NMDS analysis, where lower lotic habitats shared more than $90 \%$ of similarity, both being inhabited by only two species: predominantly lotic $O$. forcipatus and eurytopic $P$. pennipes. It was surprising that lower lotic habitats did not support higher dragonfly species richness, as they showed to be a favored habitat for some other aquatic insects, such as mayflies (Vilenica et al., 2017) and aquatic dance flies (Ivković et al., 2010). Thus, future studies should include a higher number of study sites and microhabitats in lower lotic habitats, which could reveal higher dragonfly diversity. Due to the similar environmental factors and microhabitat composition, tufa barriers and lower lotic habitats shared 50\% similarity, having two common species: $O$. forcipatus and $P$. pennipes. Differences between the two habitat types were obvious from lower species richness in lower lotic habitats, i.e. absence of lakeloving species, and absence of expected riverine species, such as G. vulgatissimus (Dijkstra and Lewington, 2006).

This study confirmed that there is a strong relationship between distribution of freshwater benthic organisms and water temperature, dissolved oxygen concentration, nutrients, water velocity and substrate type (Corbet, 1964; Giller and Malmqvist, 1998; Moog, 2002; Allan and Castillo, 2007). In accordance with their previously recorded preferences for environmental factors (Corbet and Brooks, 2008; Pešić et al., 2017), dragonfly larvae of the Plitvice Lakes hydrosystem favored habitats with higher water temperature, i.e. tufa barriers. Water temperature is strongly and conversely linked to oxygen concentration (Moog, 2002), which was also shown to be of high importance in structuring dragonfly assemblages in the studied hydrosystem. Oxygen concentrations in cold karst rivers generally fluctuate between 10 and $12 \mathrm{mg} \mathrm{L}^{-1}$ (Štambuk-Giljanović, 2005), therefore in the studied tufadepositing habitats, water was well oxygenated (average in the range $10.1-11.1 \mathrm{mg} \mathrm{L}^{-1}$ ). Nevertheless, as dragonfly larvae preferred habitats with higher water temperature, they also exhibited correlation with lower concentrations of dissolved oxygen. The majority of the recorded species inhabit either a wide range of freshwater habitats, or slow-flowing and standing water bodies (Dijkstra and Lewington, 2006). These habitats are often associated with higher water temperature and lower oxygen concentration compared to fast flowing streams (Giller and Malmquist, 1998; Wetzel, 2001). According to CCA analysis, ammonium concentration also had high influence on dragonfly larvae, and a majority of species were recorded at the sites with elevated ammonium concentrations. 
Table 4. Spearman's rank significant correlation coefficient $(R)$ for dragonfly assemblages $(\mathrm{S}$ and $\mathrm{N})$ and physico-chemical water properties in Plitvice Lakes NP. Sample size $(N)=366, * * * p<0.001, * * p<0.01, * p<0.05$.

\begin{tabular}{|c|c|c|c|c|}
\hline Dragonfly assemblages & Physico-chemical water properties & $R$ & $t(N-2)$ & $p$-Value \\
\hline \multirow{4}{*}{ Species richness $(\mathrm{S})$} & Oxygen concentration & -0.19 & -3.64 & $* * *$ \\
\hline & Conductivity & -0.42 & -8.78 & $* * *$ \\
\hline & Alkalinity & -0.41 & -8.65 & $* * *$ \\
\hline & Ammonium ions & 0.11 & 2.17 & $*$ \\
\hline \multirow[t]{4}{*}{ Abundance $(\mathrm{N})$} & Water temperature & 0.27 & 5.27 & $* * *$ \\
\hline & Oxygen concentration & -0.19 & -3.63 & $* * *$ \\
\hline & $\mathrm{pH}$ & 0.34 & 6.82 & $* * *$ \\
\hline & Conductivity & -0.43 & -8.95 & $* * *$ \\
\hline
\end{tabular}

Table 5. Spearman's rank significant correlation coefficient $(R)$ for five dragonfly species and physico-chemical water properties in Plitvice Lakes NP. Sample size $(N)=366,{ }^{* * *} p<0.001,{ }^{* *} p<0.01,{ }^{*} p<0.05$.

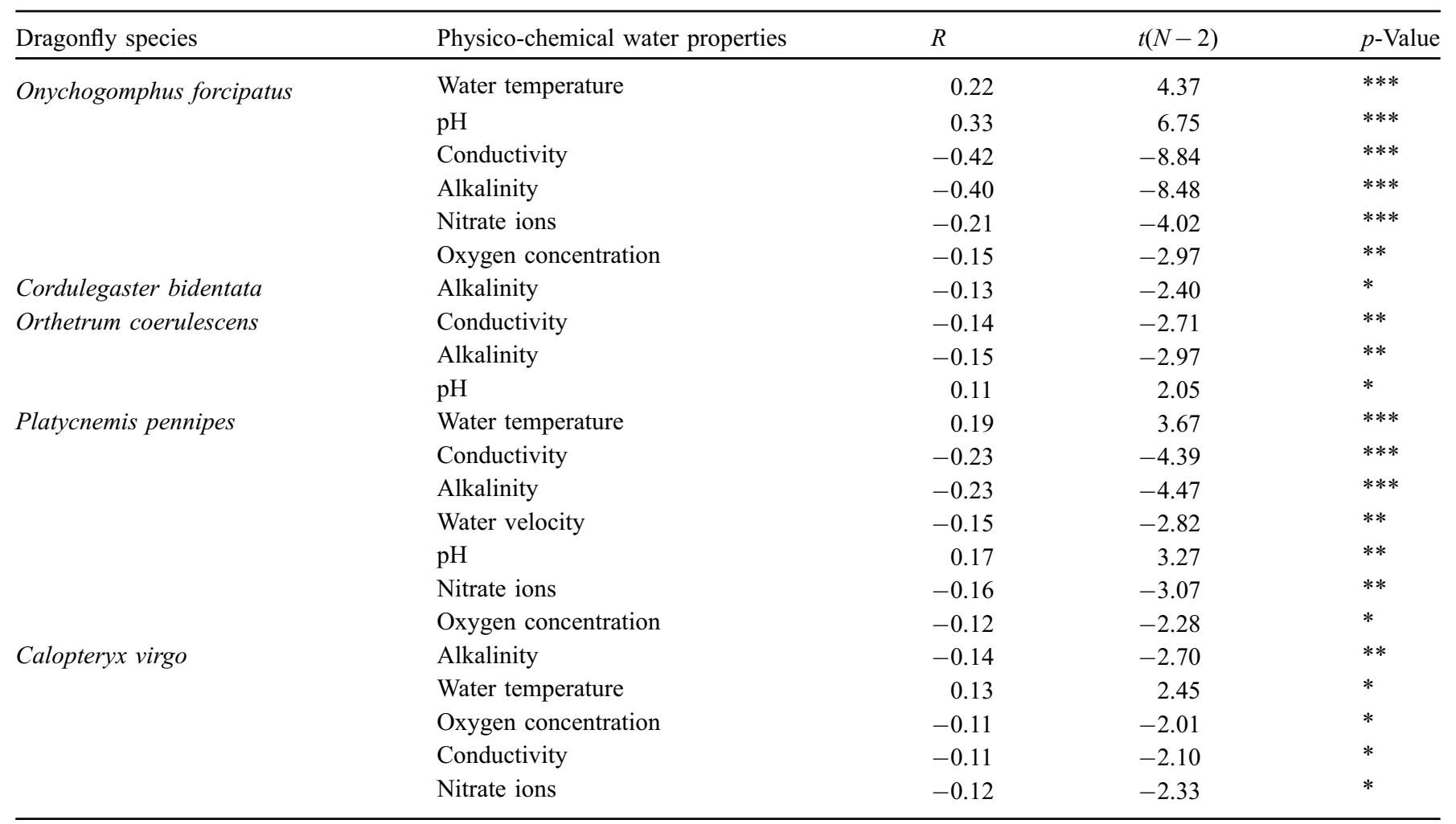

The pressure from tourism activities in the NP began to increase several decades ago (Petrik, 1961; Matoničkin and Pavletić, 1967), and is most probably the reason for slightly elevated concentrations of ammonium that were recorded. However, these values are still under the allowed limits $\left(0.09 \mathrm{mg} \mathrm{L}^{-1}\right)$ (WHO, 1986), and at present, are not considered a limiting factor for inhabiting species. Thus, dragonflies probably inhabited sites with elevated ammonium concen- trations because these sites were also associated with higher water temperature. Nevertheless, due to the increasing anthropogenic pressure, ammonium concentrations could increase more in the near future, leading also to the elevation of phosphate concentrations and consequently change biological productivity (Špoljar, 2013). This should be taken into account while managing and protecting this unique karst hydrosystem and its communities. The most important 

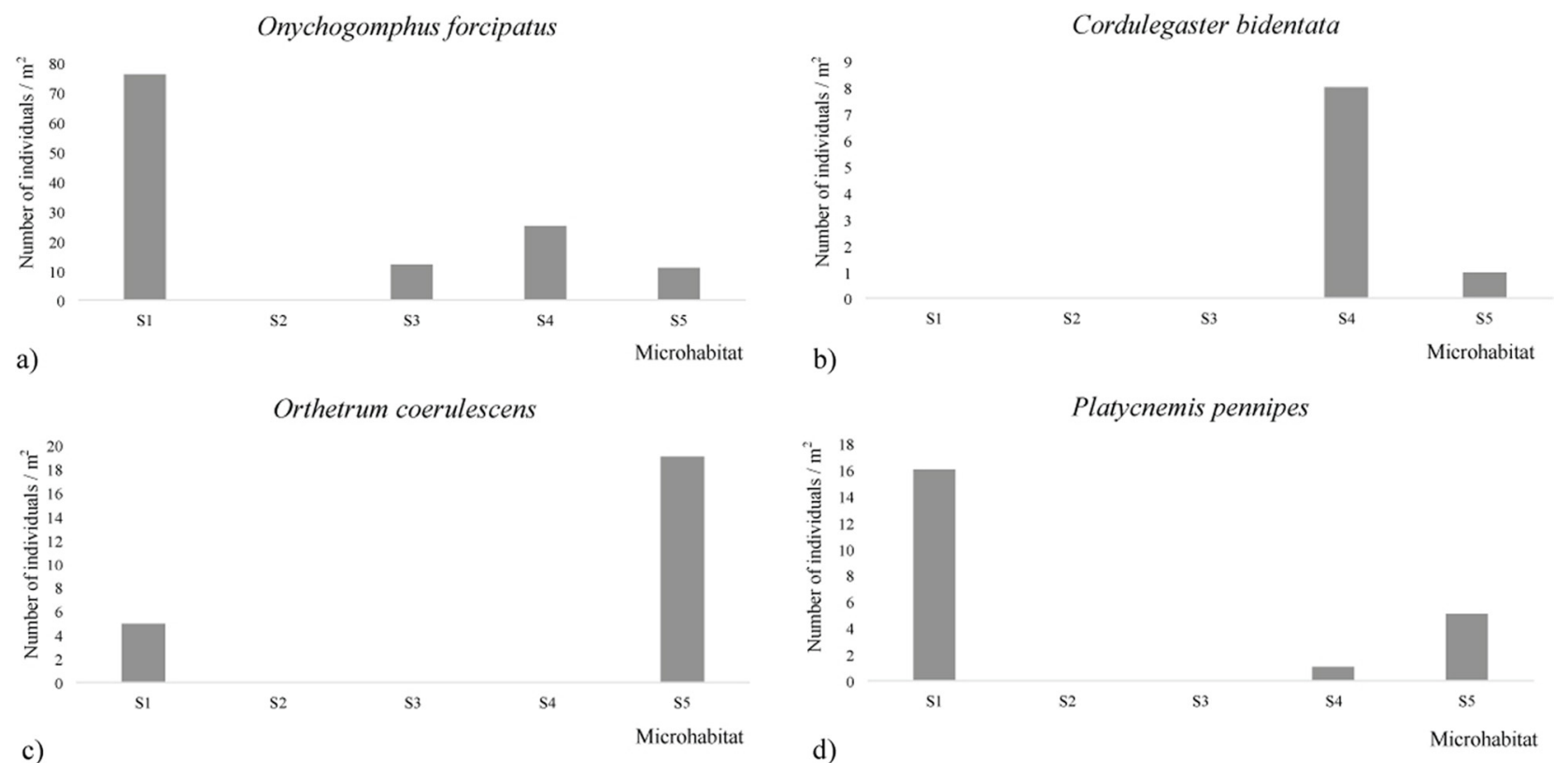

c)

Calopteryx virgo

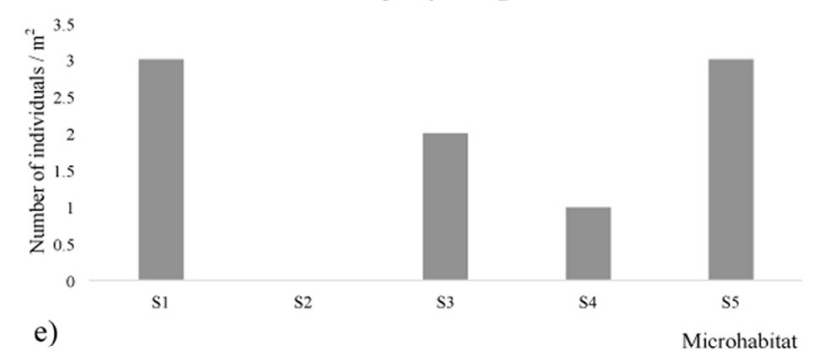

Fig. 4. Number of dragonfly individuals per $\mathrm{m}^{2}$ for four most abundant species at different microhabitats in Plitvice Lakes NP: (a) Onychogomphus forcipatus, (b) Cordulegaster bidentata, (c) Orthetrum coerulescens, (d) Platycnemis pennipes and (e) Calopteryx virgo. Legend: S1 = cobbles, S2 = angiosperms, S3 = mosses, S4 = sand, S5 = silt with leaf litter.

components of freshwater microhabitats are substrate type and associated water velocity (Lampert and Sommer, 1997). Differences in diversity of dragonfly larvae among the microhabitats are related to prey distribution (i.e. food availability) and substrate suitable for various larval activities (e.g. resting, movement, hiding from predators) (Minshall, 1984; Corbet and Brooks, 2008). The majority of species in the studied tufa-depositing habitats avoided mosses, characterized by the highest water speed. On the other hand, microhabitats with slower velocities, such as cobbles and sand, were more abundant and species rich. Significant preference of $O$. forcipatus for microhabitats with cobbles was in accordance with the previous studies (e.g. Kitanova et al., 2008). Rheo to limnophilous $O$. coerulescens (Schmedtje and Colling, 1996) was mainly recorded on silt with leaf litter, with the slowest water velocity, which confirmed species preference for muddy substrate (e.g. Wildermuth, 2008). Limno to rheophilous $P$. pennipes (Schmedtje and Colling, 1996) was correlated with slower velocity, as it preferentially inhabited microhabitats with inorganic substrates, and strongly avoided mosses. Although the larvae of species belonging to the family Cordulegastridae inhabit small streams and brooks, they live as shallow burrowers in the sediment (e.g. Buchwald, 1998; Ferreras-Romero and Corbet, 1999; Lang et al., 2001). Thus, the highest abundance of $C$. bidentata being recorded on sand, with slow water current, is not surprising and confirms its preference for soft substrates and moderate water flow due to high sensitivity of the species to drift during high flow episodes (Askew, 2004; Leipelt, 2005).

\section{Conclusions}

The current study represents an important contribution to the knowledge of dragonfly fauna and distribution, but also their preferences for habitat, microhabitat and environmental factors in lotic habitats in the Dinaric Western Balkans. Dragonfly assemblages were primarily influenced by physicochemical water properties that are related to the position within the studied barrage-lake system. Microhabitat characteristics also played an important role, as dragonfly larvae preferred microhabitats with inorganic substrates (i.e. cobbles and sand) and slower water velocity, and mainly avoided mosses associated with the strongest current. Comprehensive knowledge of faunal composition, distribution and dragonfly ecological traits can enable high-quality classification of karst freshwater habitats and support their protection. Future activities should include systematic ecological studies in the whole area of Plitvice Lakes NP (i.e. higher number of habitats 
and microhabitats), with special emphasis on dragonfly exuviae and adults.

Acknowledgements. The comprehensive macroinvertebrate study at Plitvice Lakes NP was conducted based on permissions of Ministry of Environmental and Nature Protection of Republic of Croatia (RN: 532-08-02-1/7-06-3; 532-08-02-1/7-06-3). The study is a result of Projects No. 119-1193080-1206 (PL: Mladen Kučinić) and No. 119-1193080-3076 (PL: Mladen Kerovec) supported by the Croatian Ministry of Science, Education and Sports. Prof. Dr. Mladen Kučinić and Prof. Dr. Mladen Kerovec are thanked for financial support. Additionally, Prof. Dr. Mladen Kučinić's advices and initiation of the systematic studies on the Park's fauna are greatly appreciated. Many thanks to Prof. Dr. Mladen Kučinić, Dr. Vlatka Mičetić-Stanković, Asst. Prof. Dr. Marija Ivković, Dr. Igor Stanković, Prof. Dr. Zlatko Mihaljević, Assoc. Prof. Dr. Petar Kružić, Andreja Komljenović, Martina Krbavčić, Sanja Žalac, Bruno Polak, Matija Šimac, Mr. Ivančica Krulik and Mirjana Jelenčić for collecting the samples and for help in sorting the collected material. Many thanks to Miran Katar for help with the artwork, and Kerry Mackay for her helpful comments on language style. Finally, I would also like to thank the reviewers for their useful comments and suggestions that markedly improved this manuscript.

\section{References}

Allan JD, Castillo MM. 2007. Stream ecology: structure and function of running waters. Dordrecht: Springer, $436 \mathrm{p}$.

Antonović I, Treer T. 2015. A review of freshwater ichthyofauna research published in the Croatian Journal of Fisheries since 1938. Croat J Fish 73(4): 176-182.

Askew RR. 2004. The dragonflies of Europe, 2nd ed. Essex: Harley Books, 308 p.

Belančić A, Bogdanović T, Franković M, Ljuština M, Mihoković N, Vitas B 2008. Crvena knjiga vretenaca Hrvatske, Ministarstvo kulture. Zagreb: Državni zavod za zaštitu prirode Republike Hrvatske, 132 p. (in Croatian).

Bogdanović T, Merdić E, Mikuska J. 2008. Data to the dragonfly fauna of the lower Neretva River. Entomol Croat 12 (2): 51-65.

Bonacci O, Jelin J. 1988. Identification of a karst hydrological system in the Dinaric karst (Yugoslavia). Hydrol Sci J 33: 483-497.

Bonacci O, Pipan T, Culver DC. 2009. A framework for karst ecohydrology. Environ Geol 56: 891-900.

Bonacci O, Željković I, Galić A. 2013. Karst rivers' particularity: an example from Dinaric karst (Croatia/Bosnia and Herzegovina). Environ Earth Sci 70: 963-974.

Boudot J-P, Kalkman VJ, eds. 2015. Atlas of the European dragonflies and damselflies. The Netherlands: KNNV Publishers, $381 \mathrm{p}$.

Boudot J-P, Kalkman VJ, Azpilicueta M, Amorín T, Bogdanović T, Cordero Rivera A, Degabriele G, Dommanget J-L, Ferreira S, Garrigós B, Jović M, Kotarac M, Lopau W, Marinov M, Mihoković N, Riservato E, Samraoui B, Schneider W. 2009. Atlas of the Odonata of the Mediterranean and North Africa. Libellula Supplement 9: 1-256.

Brochard C, Groendijk D, van der Ploeg E, Termaat T. 2012. Fotogids Larvenhuidjes van Libellen. Zeist: KNNV uitgeverij, 320 p.

Buchwald R. 1988. Die gestreifte Quelljungfer Cordulegaster bidentatus (Odonata) in Süd Westdeutschland. Carolinea 46: 49-64.
Buchwald R. 1992. Vegetation and dragonfly fauna - characteristics and examples of biocenological field studies. Vegetatio 101:99-107.

Calijuri ML, do Couto EA, Santiago AF, Camargo RA, Silva MDFM. 2012. Evaluation of the influence of natural and anthropogenic processes on water quality in karstic region. Water Air Soil Pollut 223: 2157-2168.

Carrara F. 1846. La Dalmazia descritta, Fratteli Battala tipografi editori, Zadar.

Clarke KR, Gorley RN. 2006. PRIMER V6: user manual/tutorial. Plymouth: Primer-E.

Corbet PS. 1964. Temporal patterns of emergence in aquatic insects. Can Entomol 96: 264-279.

Corbet PS. 1993. Are Odonata useful as bioindicators? Libellula 12: 91-102.

Corbet P, Brooks S. 2008. Dragonflies, Collins New Naturalist Library series, Book 106. London: Harper Collins, 480 p.

De Knijf G, Vanappelghem C, Demolder H. 2013. Odonata from Montenegro, with notes on taxonomy, regional diversity and conservation. Odonatologica 42 (1): 1-29.

Dijkstra K-DB, Lewington R. 2006. Field guide to the dragonflies of Britain and Europe. Gillingham: British Wildlife Publishing, 320 p.

Dittmar H. 1955. Ein Sauerlandbach: Untersuchungenan einem Wiesenmittelgebirgsbach. Arch Hydrobiol 50: 305-522.

Ferreras-Romero M, Corbet PS. 1999. The life cycle of Cordulegaster boltonii (Donovan, 1807) (Odonata: Cordulegastridae) in the Sierra Morena Mountains (southern Spain). Hydrobiologia 405: 39-48.

Gerken B, Sternberg K. 1999. Die Exuvien Europaïscher Libellen The exuviae of European Dragonflies (Insecta, Odonata), Arnika \& Eisvogel, Hökster \& Jena, 354 p.

Giller PS, Malmqvist B. 1998. The biology of streams and rivers. New York: Oxford University Press, 296 p.

Gligora Udovič M, Cvetkoska A, Žutinić P, Bosak S, Stanković I, Špoljarić I, Mršić G, Kralj Borojević K, Ćukurin A, PlenkovićMoraj A. 2017. Defining centric diatoms of most relevant phytoplankton functional groups in deep karst lakes. Hydrobiologia 788(1): 169-191.

Grimaldi D, Engel MS. 2005. Evolution of the insects. New York: Cambridge University Press, 755 p.

Habdija I, Primc-Habdija B, Matoničkin R, Kučinić M, Radanović I, Miliša M, Mihaljević Z. 2004. Current velocity and food supply as factors affecting the composition of macroinvertebrates in bryophyte habitats in karst running water. Biologia 59 (5): 577-593.

Hawking JH, New TR. 1999. The distribution patterns of dragonflies (Insecta: Odonata) along the Kiewa River, Australia, and their relevance in conservation assessment. Hydrobiologia 392: 249-260.

Horning CE, Pollard JE. 1978. Macroinvertebrate sampling techniques for streams in semi-arid regions: comparison of the Surber method and unit-effort traveling Kick method. Report number EPA 600-4-78-040. Washington: US EPA, 37 p.

IUCN. 1979. IUCN review. World Heritage Nomination. Lake Plitvice National Park.

Ivković M, Miliša M, Mihaljević Z. 2010. The aquatic dance flies' fauna (Diptera, Empididae: Hemerodromiinae and Clinocerinae) of the Plitvice Lakes National Park. Nat Croat 19 (1): 133-139.

Ivković M, Mičetić Stanković V, Mihaljević Z. 2012. Emergence patterns and microhabitat preference of aquatic dance flies (Empididae; Clinocerinae and Hemerodromiinae) on a longitudinal gradient of barrage lake system. Limnologica 42: 43-49.

Ivković M, Kesić M, Mihaljević Z, Kúdela M. 2013. Emergence patterns and ecological associations of some haematophagous blackfly species along an oligotrophic hydrosystem. Med Vet Entomol 28: 94-102. 
Janecek BFU, Moog O, Waringer J. 1995. Odonata. In: Moog O, ed. Fauna Aquatica Austriaca, Lieferungen 1995, 2002, Wasserwirtschaftskataster. Wien: Bundesministerium für Land- und Forstwirtschaft, Umwelt und Wasserwirtschaft.

Kalkman VJ, Clausnitzer V, Dijkstra K-DB, Orr GA, Paulson RD, Tol JV. 2008. Global diversity of dragonflies (Odonata) in freshwater. Hydrobiologia 595: 351-363.

Kitanova D, Slavevska Stamenković V, Kostov V, Marinov M. 2008. Contribution to the knowledge of dragonfly fauna of the Bregalnitsa river, Macedonia (Insecta: Odonata). Nat Montenegr 7(2): 169-180.

Knight TM, McCoy MW, Chase JM, McCoy KA, Holt RD. 2005. Trophic cascades across ecosystems. Nature 437: 880-883.

Kučinić M, Previšić A, Graf W, Mihoci I, Šoufek M, StanićKoštroman S, Lelo S, Vitecek S, Waringer J. 2015. Larval description of Drusus bosnicus Klapálek 1899 (Trichoptera: Limnephilidae) with distributional molecular and ecological features. Zootaxa 3957 (1): 85-97.

Kulijer D, De Knijf G, Franković M. 2013. Review of the Odonata of Bosnia and Herzegovina. Odonatologica 42 (2): 109-123.

Lampert W, Sommer U. 1997. Limnoecology: the ecology of lakes and streams. Oxford: Oxford University Press, 323 p.

Lang C, Müller H, Waringer JA. 2001. Larval habitats and longitudinal distribution patterns of Cordulegaster heros Theischinger and $C$. bidentata Selys in an Austrian forest stream (Anisoptera: Cordulegastridae). Odonatologica 30: 395-409.

Leipelt KG. 2005. Behavioural differences in response to current: implications for the longitudinal distribution of stream odonates. Arch Hydrobiol 163 (1): 81-100.

Manenti R, Siesa ME, Ficetola F. 2013. Odonata occurrence in caves: active or accidentals? A new case study. J Cave Karst Stud 75(3): 205-209.

Márquez-Rodríguez J. 2015. Observaciones odonatológicas en un río extremo - acidófilo (Andalucía, Sur de España). Arquivos Entomológicos 14: 63-66 (in Spanish).

Martín R, Maynou X. 2016. Dragonflies (Insecta: Odonata) as indicators of habitat quality in Mediterranean streams and rivers in the province of Barcelona (Catalonia, Iberian Peninsula). Int $J$ Odonatol 19(3): 107-124.

Matoničkin I. 1959. Faunistička istraživanja reikotopnih biotopa na Plitvičkim jezerima. Ljetopis 63: 355-360 (in Croatian).

Matoničkin I, Pavletić Z. 1967. Hidrologija potočnog Sistema Plitvičkih jezera i njegove ekološko-biocenološke značajke. Křs Jugoslavije 5: 83-126 (in Croatian).

Matoničkin I, Pavletić Z, Tavčar V, Krkač N. 1971. Limnološka istraživanja reikotopa $\mathrm{i}$ fenomena protočne travertinizacije $\mathrm{u}$ Plitvičkim jezerima. The limnological investigations of reicotops and phenomenon of current travertinisation in Plitvička jezera (Plitvice Lakes, Yugoslavia). Acta Biol 7(1): 1-87 (in Croatian).

Mičetić Stanković V, Jäch MA, Kučinić M. 2015. Annotated checklist of Croatian riffle beetles (Insecta: Coleoptera: Elmidae). Nat Croat 24(1): 93-109.

Mihevc A, Zupan-Hajna N, Prelovšek M. 2010. Case study from the Dinaric karst of Slovenia. In: Mihevc A, Prelovšek M, ZupanHajna N, eds. Introduction to the Dinaric karst. Postojna: Karst Research Institute, pp. 49-66.

Miliša M, Habdija I, Primc-Habdija B, Radanović I, Matoničkin Kepčija R. 2006. The role of flow velocity in the vertical distribution of particulate organic matter on moss-covered travertine barriers of the Plitvice Lakes (Croatia). Hydrobiologia 553: 231-243.

Minshall GW. 1984. Aquatic insect-substratum relationship. In: Resh VH, Rosenberg DM, eds. The ecology of aquatic insects. New York: Praeger Scientific, pp. 358-400.
Moog O, ed. 2002. Fauna Aquatica Austriaca, Edition 2002, Wassserwirtschaftskataster. Vienna: Bundesministerium für Land und Forstwirtschaft, Umwelt und Wasserwirtschaft.

Moore NW. 1997. Status survey and conservation action plan. Dragonflies. IUCN/SSC Odonata Specialist Group. Gland and Cambridge: IUCN.

Mortimer SR, Hollier JA, Brown VK. 1998. Interactions between plant and insect diversity in the restoration of lowland calcareous grasslands in southern Britain. Appl Veg Sci 1: 101-114.

Pešić V, Gligorović B, Savić A, Buczyński P. 2017. Ecological patterns of Odonata assemblages in karst springs in central Montenegro. Knowl Manag Aquat Ecosyst 418: 3.

Petrik M. 1961. Temperatura i kisik Plitvičkih jezera. Zagreb: JAZU, pp. 1-37 (in Croatian).

Popijač A, Sivec I. 2009. Diversity and distribution of stoneflies in the area of Plitvice Lakes National Park and along the Mediterranean river Cetina (Croatia). Aquat Insect 31(1): 731-742.

Raebel EM, Merckx T, Riordan P, Macdonald DW, Thompson DJ. 2010. The dragonfly delusion: why it is essential to sample exuviae to avoid biased surveys. $J$ Insect Conserv 14: 523-534.

Samways MJ, McGeoch MA, New TR. 2009. Insect conservation: handbook of approaches and methods. Oxford: Oxford University Press, $432 \mathrm{p}$.

Schmedtje U, Colling M. 1996. Ökologische Typisierung der aquatischen Makrofauna. Informationsberichte des Bayerischen Landesamtes für Wasserwirtschaft, 4/96, $543 \mathrm{p}$.

Schorr M, Paulson D. 2017. World Odonata list, https://www. pugetsound.edu/academics/academic-resources/slater-museum/ biodiversity-resources/dragonflies/world-odonata-list2/ (accessed on: 2017/24/05)

Šegota T, Filipčić A. 2003. Köppenova podjela klima i hrvatsko nazivlje. Geoadria 8(1): 17-23 (in Croatian).

Šemnički P, Previšić A, Ivković M, Čmrlec K, Mihaljević Z. 2012. Tufa barriers from a caddisfly's point of view: streams or Lake Outlets? Int Rev Hydrobiol 97 (6): 465-484.

Sertić Perić M, Miliša M, Matoničkin Kepčija R, Primc-Habdija B, Habdija I. 2011. Seasonal and fine-scale spatial drift patterns in tufa-depositing barrage hydrosystem. Fund Appl Limnol 178(2): 131-145.

Sertić Perić M, Jakopović S, Primc B. 2015. Seasonal drift-benthos trends on a moss-covered tufa barrier within a karst barrage hydrosystem (Plitvice Lakes, Croatia). Nat Croat 24(2): 223-246.

Srdoč D. 1985. Procesi taloženja kalcita u krškim vodama s posebnim osvrtom na Plitvička jezera. Krš Jugoslavije 11: 4-6.

Steytler NS, Samways MJ. 1995. Biotope selection by adult male dragonflies (Odonata) at an artifical lake created for insect conservation in South Africa. Biol Conserv 72: 381-386.

Stilinović B, Božičević S. 1998. The Plitvice Lakes - a natural phenomenon in the middle of the Dinaric karst in Croatia. Eur Water Manag 5: 15-24.

Špoljar M. 2013. Microaquatic communities as indicator of environmental changes in lake ecosystems. J Eng Res - Kuwait 1: $29-42$.

Špoljar M, Primc-Habdija B, Habdija I. 2007. Transport of seston in the karstic hydrosystem of the Plitvice Lakes (Croatia). Hydrobiologia 579: 199-209.

Štambuk-Giljanović N. 2005. The quality of water resource in Dalmatia. Environ Model Assess 104: 235-267.

Štih A, Koren T, Bobinec A, Matejči, M, Franković M. 2015. The River Zrmanja - another hotspot of dragonfly diversity in the Dinaric Karst, Croatia. Entomol Croat 19 (1-2): 43-57.

Ter Braak CJF, Šmilauer P. 1998. Canoco for windows: software for canonical community ordination (version 4.02 ). Wageningen, The Netherlands: Centre for Biometry Wageningen, CPRODLO. 
Vilenica M, Dijkstra K-DB. 2014. The dragonfly (Insecta, Odonata) fauna of the Banovina region, Croatia. Nat Croat 23 (1): 45-66.

Vilenica M, Mičetić Stanković V, Franković M. 2011. Dragonfly fauna (Insecta, Odonata) in the Turopolje region (Croatia). Nat Croat 20(1): 141-158.

Vilenica M, Gattolliat J-L, Ivković M, Kučinić M, Mičetić Stanković V, Mihaljević Z, Sartori M. 2014. The mayfly fauna (Insecta, Ephemeroptera) of the Plitvice Lakes National Park, Croatia. Nat Croat 23(2): 349-363.

Vilenica M, Alegro A, Koletić N, Mihaljević Z. 2016a. New evidence of Lindenia tetraphylla (Vander Linden, 1825) (Odonata, Gomphidae) reproduction at the north-western border of its distribution. Nat Croat 25 (2): 287-294.

Vilenica M, Previšić A, Ivković M, Popijač A, Vučković I, Kučinić M, Kerovec M, Gattolliat J-L., Sartori M, Mihaljević Z. 2016b. Mayfly (Insecta: Ephemeroptera) assemblages of a regulated perennial Mediterranean river system in the Western Balkans. Biologia 71 (9): 1038-1048.
Vilenica M, Mičetić Stanković V, Sartori M, Kučinić M, Mihaljević Z. 2017. Environmental factors affecting mayfly assemblages in tufa-depositing habitats of the Dinaric Karst. Knowl Manag Aquat Ecosyst 418: 14.

Wentworth CK. 1922. A scale of grade and class terms for clastic sediments. J Geol 30: 377-392.

Wetzel RG. 2001. Limnology: lake and river ecosystems, 3rd ed. San Francisco, New York, London: Academic Press (An Elsevier Science Imprint), $1006 \mathrm{p}$.

WHO - World Health Organization. 1986. Environmental Health Criteria, 54, Ammonia. http://www.inchem.org/documents/ehc/ ehc/ehc54.htm.

Wildermuth H. 2008. Habitat requirements of Orthetrum coerulescens and management of a secondary habitat in a highly manmodified landscape (Odonata: Libellulidae). Int $J$ Odonatol 11: 261-276.

Cite this article as: Vilenica M. 2017. Ecological traits of dragonfly (Odonata) assemblages along an oligotrophic Dinaric karst hydrosystem. Ann. Limnol. - Int. J. Lim. 53: 377-389 